
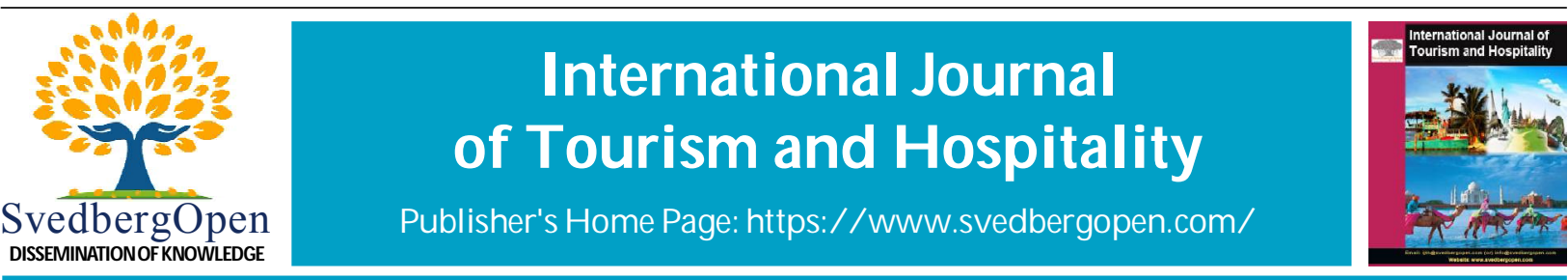

\title{
Impacts of Social Media in Promoting Food Products
}

\author{
Canet, Lena N. ${ }^{1 *}$, De Luna, Ma. Cecilia E. ${ }^{2}$ and Eleogo, Felicidad A. ${ }^{3}$ \\ ${ }^{1}$ Bulacan State University, Malolos, Bulacan, Philippines. E-mail: lena.canet@bulsu.edu \\ ${ }^{2}$ Bulacan State University, Malolos, Bulacan, Philippines. E-mail: mariacecilia.deluna@bulsu.edu.ph \\ ${ }^{3}$ Bulacan State University, Malolos, Bulacan, Philippines. E-mail: felicidad.eleogo@bulsu.edu.ph
}

\begin{tabular}{l} 
Article Info \\
\hline Volume 1, Special Issue 1, December 2021 \\
Received : 03 August 2021 \\
Accepted : 15 November 2021 \\
Published : 05 December 2021 \\
https://doi.org/10.51483/IJTH.1.S1.2021.S27-S43
\end{tabular}

\begin{abstract}
Survey questions and interviews were used to analyze the effects of social media on food product promotion. Facebook was the most popular social media channel, and positive feedback or reviews from customers were used to promote the business. The benefits of using social media include having broad access, being accessible, being cost-effective, and being fashionable. The downsides include that the firm is readily replicated, is quickly influenced by bad feedback, and is susceptible to bogus buyers. These findings imply that social media has a significant influence on the promotion of food goods.

Keywords: Social media, Food products, Promotion, Online business, Pandemic

(C) 2021 Canet, Lena N. et al. This is an open access article under the CC BY license (https://creativecommons.org/licenses/by/4.0/), which permits unrestricted use, distribution, and reproduction in any medium, provided you give appropriate credit to the original author(s) and the source, provide a link to the Creative Commons license, and indicate if changes were made.
\end{abstract}

\section{Introduction}

Websites and programs that are popular in our day are referred to as social media. Nowadays, almost everyone has a social network account. According to Pilař et al. (2021), the number of social media users is at 3.6 billion, with a forecasted increase to around 4.41 billion by 2025 . One of the most popular digital pursuits on the globe is social media. Facebook, YouTube, Instagram, Twitter, and Tiktok are just a few of the social media platforms available. Social media has also had a significant influence on the development of internet businesses. It has turned into a simple and effective tool for client sales and promotion.

Although social networking services are widely used, the best social media depends on the country and demography. In order to develop business, it is also vital to examine the popular social network in order to monitor social media events among possible clients. Sharing stories, photos, videos, status updates, and even everyday activities, as well as how we live and conduct business. Uploading videos, marketing food products through diverse content, and thumb nailing to draw viewers' attention are all common means of catching viewers' attention.

The purpose of this research is to evaluate the influence of social media on the promotion of food products. Prior to the Covid-19 Pandemic, an internet platform impacting all sorts of businesses emerged. Nowadays, lockdowns have been implemented, and many people have lost their jobs; nevertheless, internet retailers, particularly of food supplies, have sprung up.

* Corresponding author: Canet, Lena N ., Bulacan State U niversity, M alolos, Bulacan, Philippines. E-mail: Iena.can et@bulsu.edu. 


\section{Literature Review}

According to Jones et al. (2015), the impact of social media on small businesses has increase in reaching other customers on global scale through internet. Also they benefit from the use of websites to make an awareness and lot of inquiries. By the use of internet to promote product is a must especially in this time of pandemic.

In a research conducted by Pietro and Pantano (2012), it has been found out that consumers become influences by a major factor to use social media as a platform in buying decision. They realized that there is a lot of fun provided by Facebook and there is an opportunity to ask for suggestions in an entertaining and in an easy way, as well as they were motivated to pay more attention in the product promoted by Facebook. They added that social media promotes consumer to consumer approach, consumer sharing their experiences and create a common knowledge of servicing a product. Facebook can be improved by retailers by adding games, interactive application, and different contests which can attract more users. But also consumer's attitude must be handled by retailers when it comes in social media promoting.

Shankar et al. (2011), found out that social media is a tool to stay in touch with their friends and love ones. But now it has also become a place where they can learn about their consumers and the product they sell through social media sites. To reach their consumers, the retailers and marketers are utilizing the sites and providing a new way to shop.

\section{Methodology}

The researchers utilized a hybrid strategy to collect data, which included a survey and an interview. The researchers created a survey and interview instrument and distributed it to social media users in Bulacan, Philippines. The researchers looked for several online food product sites and inquired if the owner used social media accounts or platforms to promote their business. The researchers conducted and administered the survey after the respondents gave their approval. The researchers then gathered the data after answering the research question, and the findings were tallied.

These data serve as the foundation for the researchers' investigation. The responses from the survey questionnaires and interviews were encoded into the data matrix. The researchers examined the influence of Facebook as a social media platform in advertising various food products using mean, frequency, and percentage. The researchers considered ethics while doing their investigation. The business owners' permission was secured. Furthermore, all claims were properly cited, demonstrating that ethical issues were considered.

\section{Results}

Figure 1 shows that 17 or $63 \%$ of the online food business are below 1 year in operation, 4 or $14.8 \%$ are in $1-2$ years in operation, 2 or $7.4 \%$ are in $2-3$ years in operation, 2 or $7.4 \%$ are in 3 years and above in operation, 2 or $7.4 \%$ have been existing for very long. The data shows that most of the respondents are below 1 year in online business. It can be traced that these are the times when jobs have been shut down due to the pandemic. According to an article in Research and Market (2020), with more people stuck at home due to the Covid-19 outbreak, there has been a surge in demand for food delivery services.

\begin{tabular}{|l|l|}
\hline below 1 year \\
$1-2$ years \\
$2-3$ years \\
3 years and above \\
others, please specify
\end{tabular}

Figure 2 shows that 13 or $48 \%$ of businesses are different kinds of food products such as: milk tea, different types of pasta (spaghetti, carbonara, mac and cheese, lasagna), mushroom preserved, Filipino rice cake commonly called as 


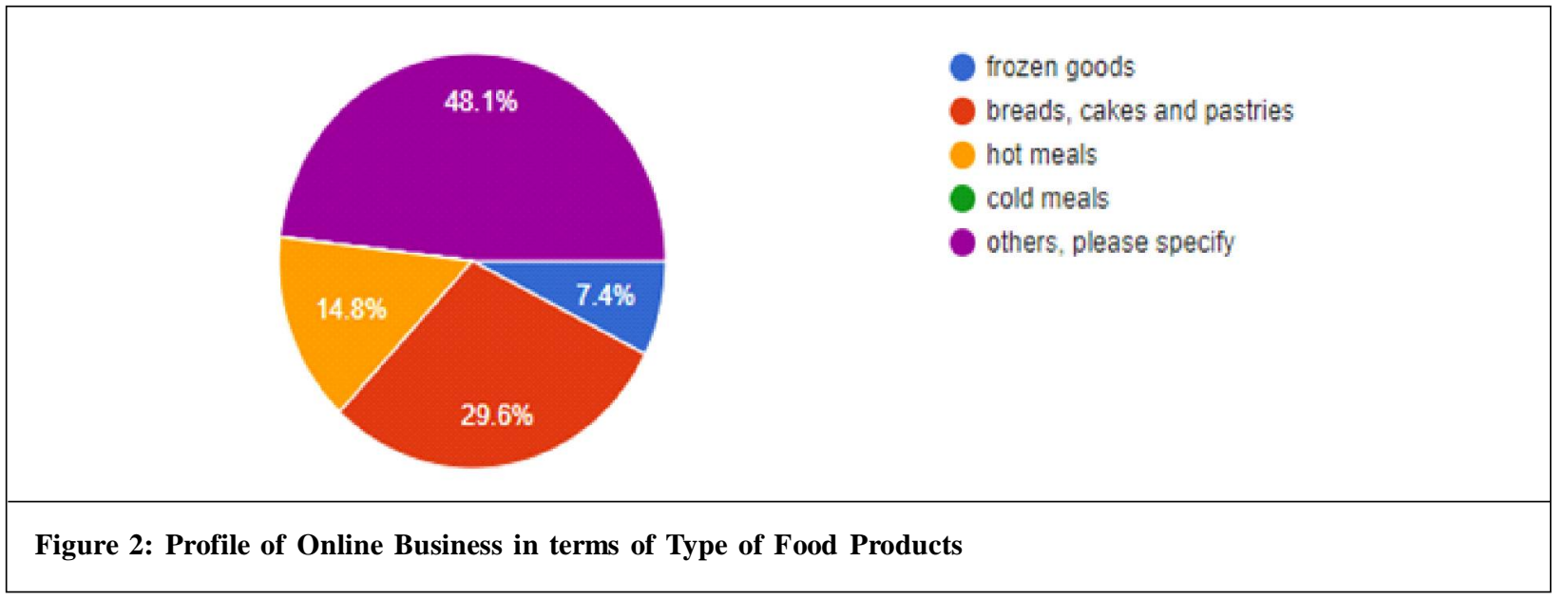

"Kakanin", Korean dishes, burgers and chips, and takoyaki, 8 or $29.6 \%$ are selling breads, cakes and pastries, 4 or $14.8 \%$ are selling hot meals, 2 or $7.4 \%$ are selling frozen goods. The data revealed that the most significant percentage of the foods being sold online are from selecting different food varieties to cater to the different taste buds of the Filipinos.

Figure 3 shows that 27 or $100 \%$ of the respondents are using Facebook as an online platform. The data revealed that all of the online food businesses in Bulacan utilizes Facebook as their online platform due to its free usage. Aside from posting text on Facebook, it also allows its user to upload photos and videos, which can be vital to communicate with consumers and potential customers.

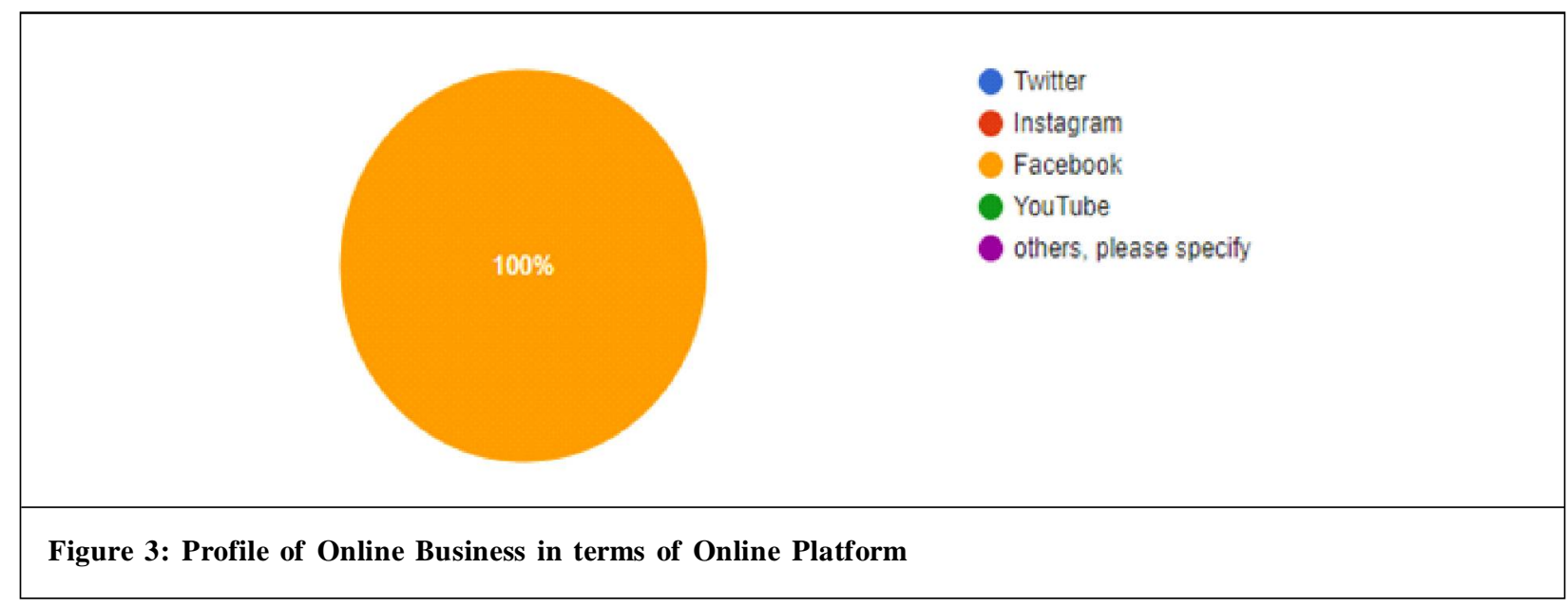

Figure 4 shows that 14 or $51.9 \%$ strongly agree that social media is better in terms of marketing cost, 12 or $44.4 \%$ are agree, 1 or $3.7 \%$ are disagree, and none strongly disagree. The data shows that most respondents strongly agree that

\begin{tabular}{|l|l|}
\hline & Strongly Agree \\
Aisagree & Strongly disagree \\
\hline & $51.9 \%$ \\
\hline
\end{tabular}


social media is better than other traditional marketing in terms of cost, like promoting on television, radio, or using printed ads are costly. Unlike in advertising on social media marketing, you can showcase your food business in the comfort of your home without breaking the bank.

Figure 5 shows that 14 or $51.9 \%$ are strongly agree that social media is better than other traditional marketing in terms of customer access, 12 or $44.4 \%$ are agree, 1 or $3.7 \%$ are disagree, and none strongly disagree. The data shows that most respondents strongly agree that social media is better than traditional marketing in customer access. The data shows that the respondents have more access to their customers in social media because almost everyone has turned to mobile phones and the internet.

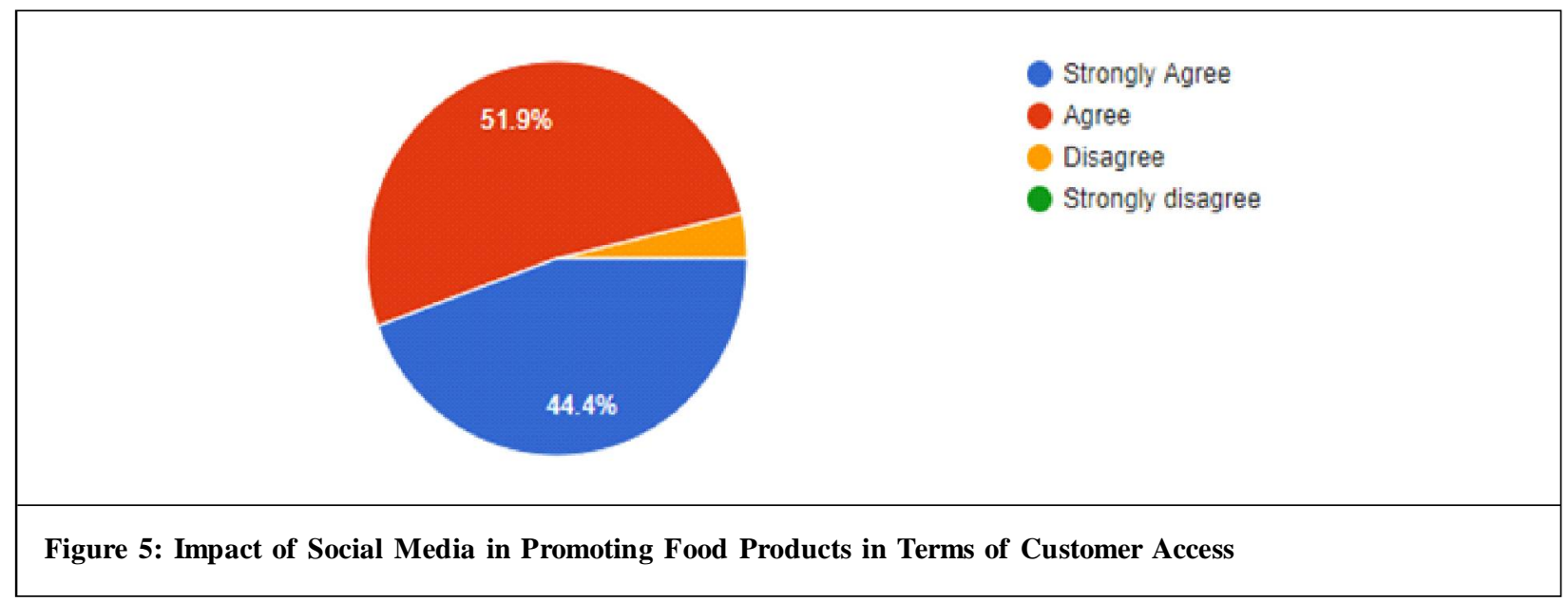

Figure 6 shows that 14 or $51.9 \%$ are strongly agree that social media is better than other traditional marketing in terms of labor, 12 or $44.4 \%$ are Agree, 1 or $3.7 \%$ are disagree, and none strongly disagree that social media is better than other traditional marketing in terms of labor. The data revealed that most respondents believe that in promoting food products, social media saves them from labor costs. There is no need to hire labor forces to promote their products and services, they will simply post text and videos and manage on their own. Thus, in expanding the business wherein social media advertising campaign is a need, digital marketing specialists will have to be hired.

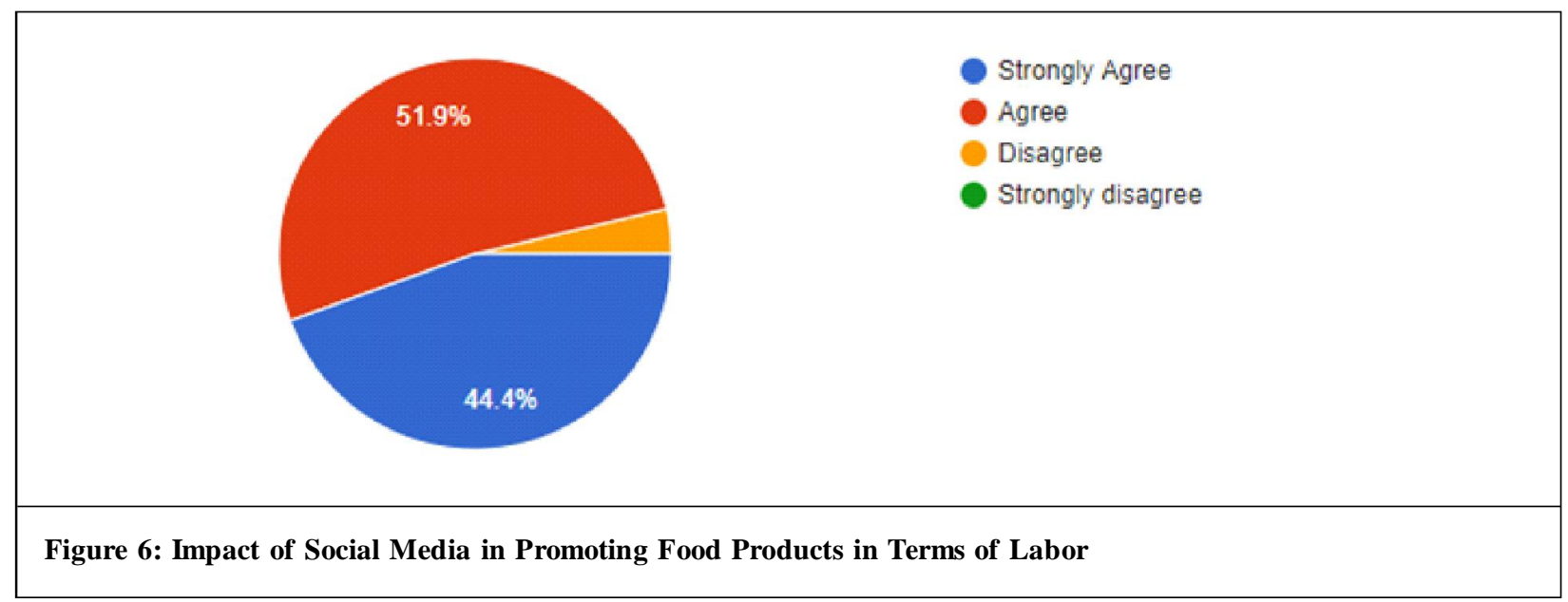

Figure 7 shows that 19 or $70.4 \%$ are strongly agree social media has increased business exposure in customer inquiry, 8 or $29.6 \%$ are agree, and none answered disagree, and strongly disagree. The data shows that social media makes it easy to draw and lead potential customers to the product and services.

Figure 8 shows that 12 or $46.2 \%$ strongly agree that social media has increased business exposure in terms of sponsorship, 12 or $46.2 \%$ are agree, 2 or $7.7 \%$ are disagree, and none strongly disagree. The data revealed that most of the respondents have positive feedback regarding the effectiveness of Facebook in sponsorships. Sponsored posts are made directly from Facebook's business profile, making them easy to create and manage. They are intended for businesses 

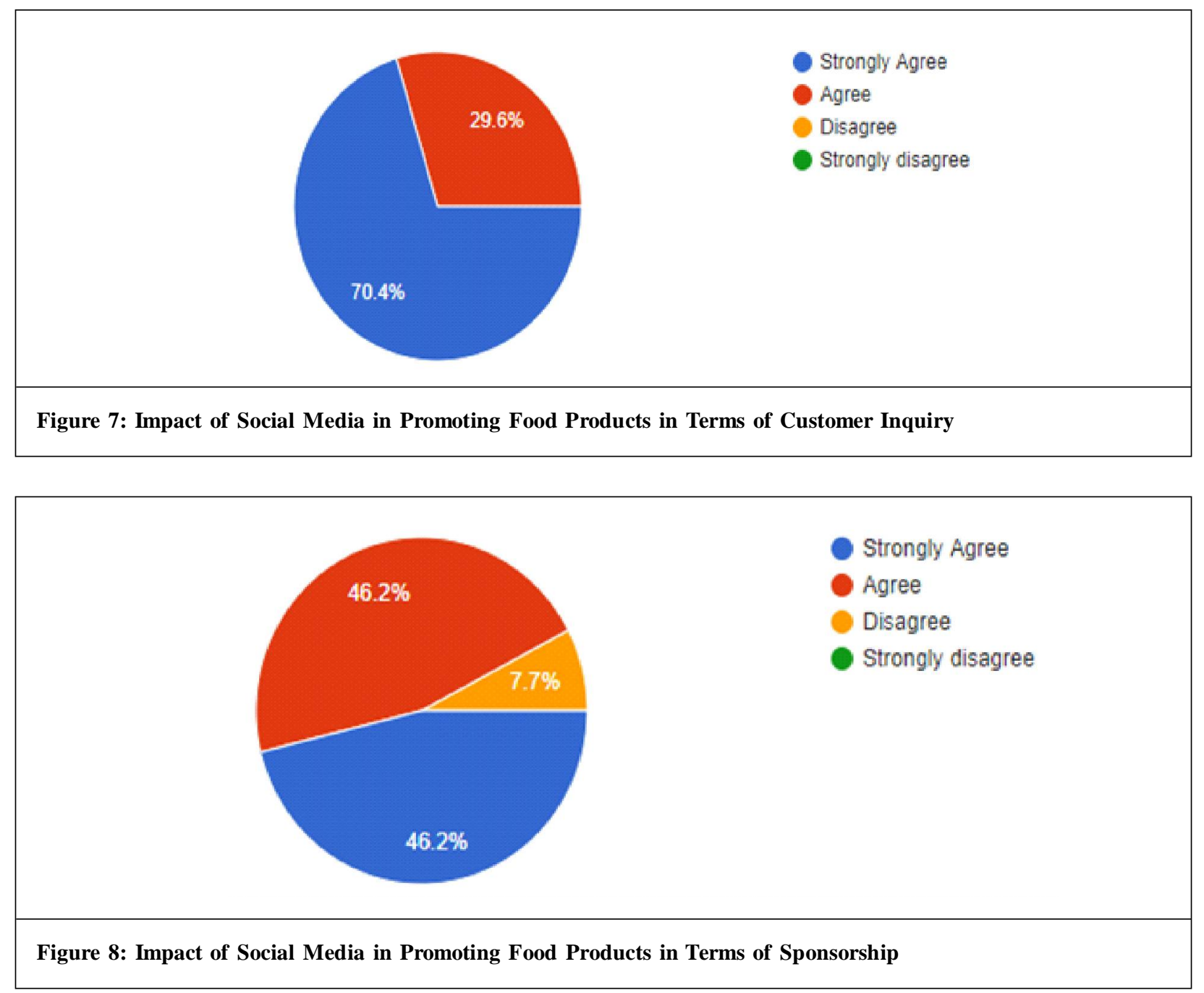

without Facebook Ads Manager's familiarity who want to develop brand awareness and are only concerned with shortterm advertising campaigns.

Figure 9 shows that 16 or $61.5 \%$ are strongly agree that social media has increased business exposure in terms of product launching, 10 or $38.5 \%$ are agree, and none are disagreeing and strongly disagreeing. The data shows that the launching of their products and services through Facebook has increased the exposure of their businesses. In his article, Fitzgerald (2019) mentioned that Millennials are 1.6 times more likely to use digital channels to learn about new products.

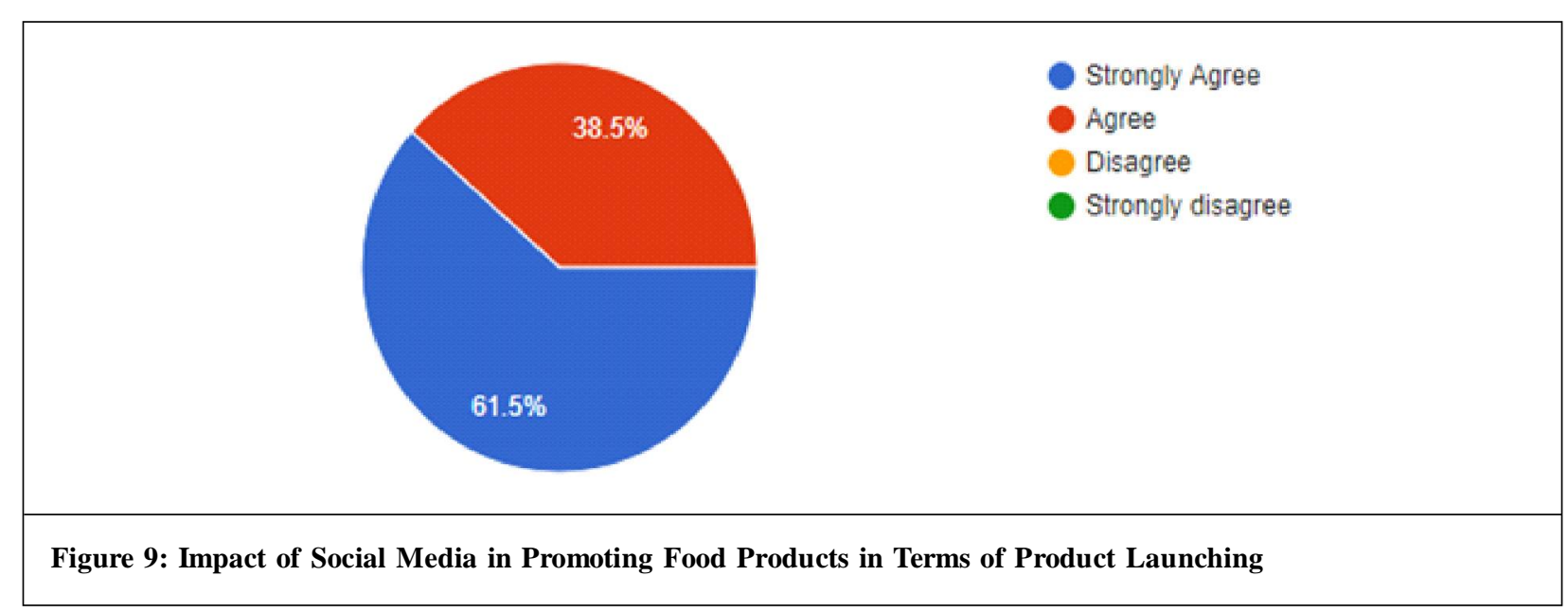


Figure 10 shows that 14 or $51.9 \%$ are strongly agree that social media used improve in terms of customer feedback, 13 or $48.1 \%$ are agree, and none disagree and strongly disagree. In a study conducted by Fitzgerald (2019), it was mentioned that consumers are $71 \%$ more likely to buy something based on social media referrals.

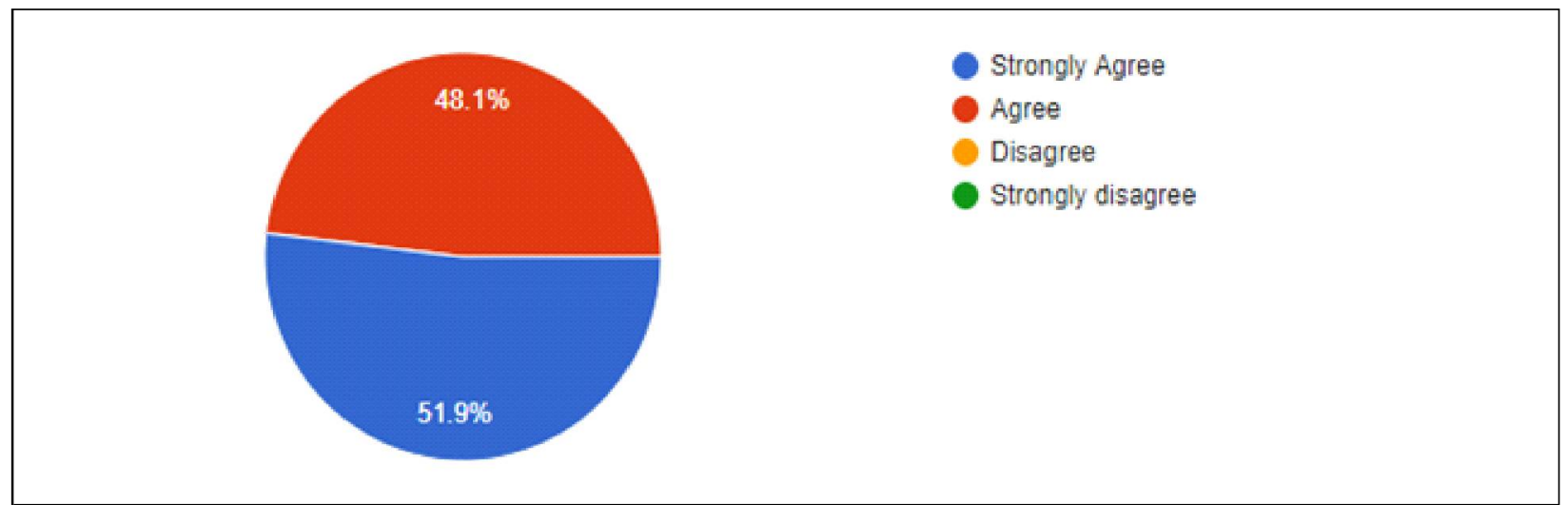

Figure 10: Impact of Social Media in Promoting Food Products in Terms of Customer Feedback

Figure 11 shows that 15 or $55.6 \%$ are strongly agree that social media improves customer satisfaction and product recommendation in terms of bulk orders, 12 or $44.4 \%$ are agree, and none disagree and strongly disagree. The data shows that customer satisfaction and product recommendation through bulk orders are high because consumers get more discounts if they purchase bulk orders. Most who take bulk orders are the re-sellers and entrepreneurs.

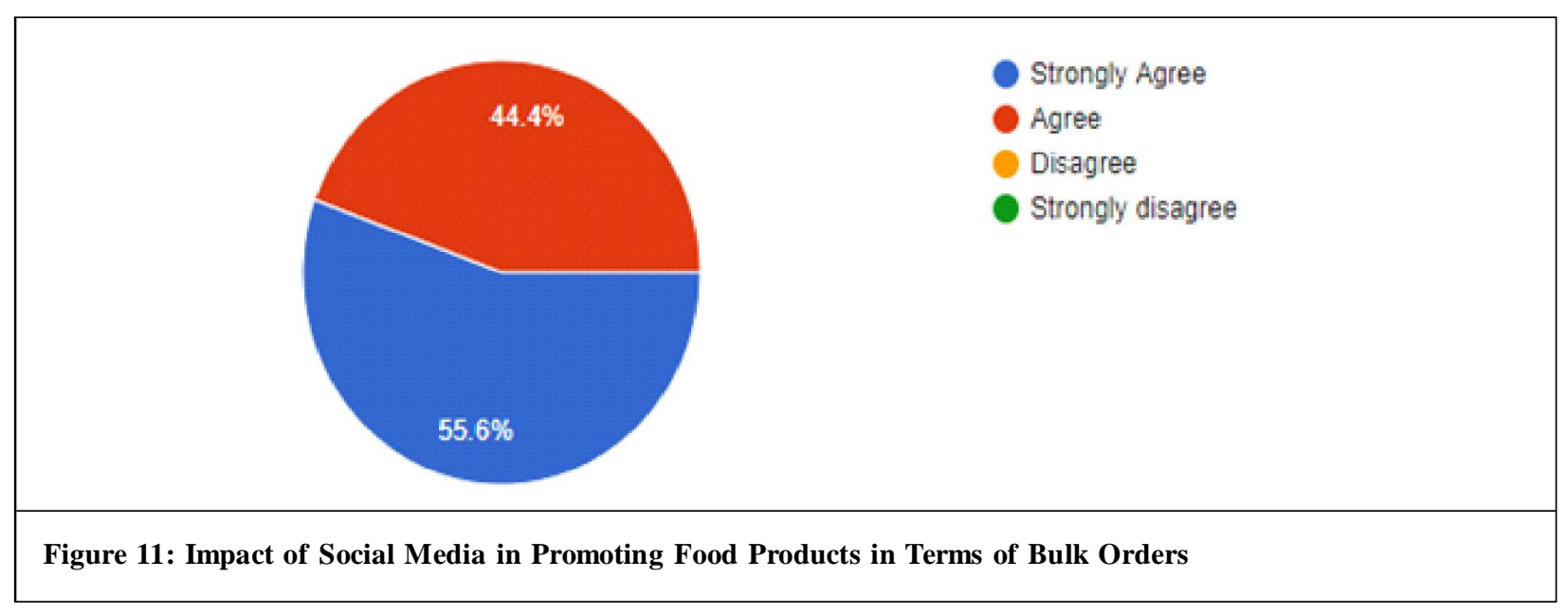

Figure 12 shows that 14 or $51.9 \%$ are strongly agree that social media improves customer satisfaction and product recommendation in terms of electronic word of mouth, 11 or $40.7 \%$ agree, 2 or $7.4 \%$ disagree, and none strongly disagree.

\begin{tabular}{|l|l|}
\hline & Agree \\
Disagree & Strongly disagree \\
\hline Figure 12: Impact of Social Media in Promoting Food Products in Terms of Electronic Word of Mouth
\end{tabular}


The data shows that mostly believes that the electronic word of mouth has affected their customer's satisfaction towards their product and services and also their product recommendation. According to Whitler (2014), in a recent study, $64 \%$ of marketing executives indicated that they believe word of mouth is the most effective form of marketing. Hennig-Thurau et al. (2004) stated that although eWOM (Electronic Word of Mouth) may be less personal than the traditional WOM (Word of Mouth), it is seen as more powerful because it has significant reach and is publicly available.

Figure 13 shows that 15 or $55.6 \%$ are strongly agree that social media help improved the product sales in the quantity of purchased products, 12 or $44.4 \%$ are Agree, and none answered disagree and strongly disagree. The data shows that all of the online food businesses are convinced that social media helped them improved their sales because of the quantity of purchased products through bulk orders.

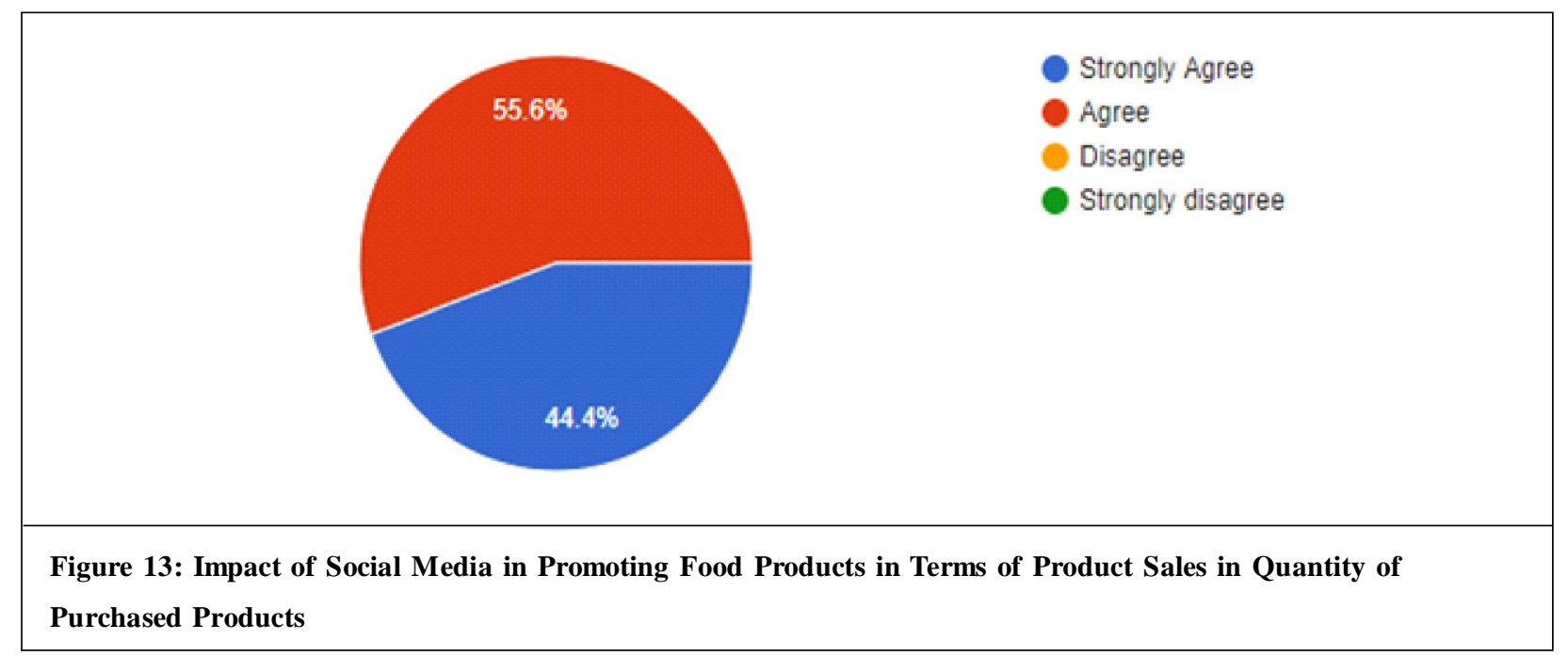

Figure 14 shows that 15 or $55.6 \%$ are strongly agree that social media help improve the product sales in the repeat purchase orders, 12 or $44.4 \%$ are Agree, and none answered disagree and strongly disagree. The data revealed that since among the customers are re-sellers and they usually purchase bulk orders, and repeat purchase orders as well.

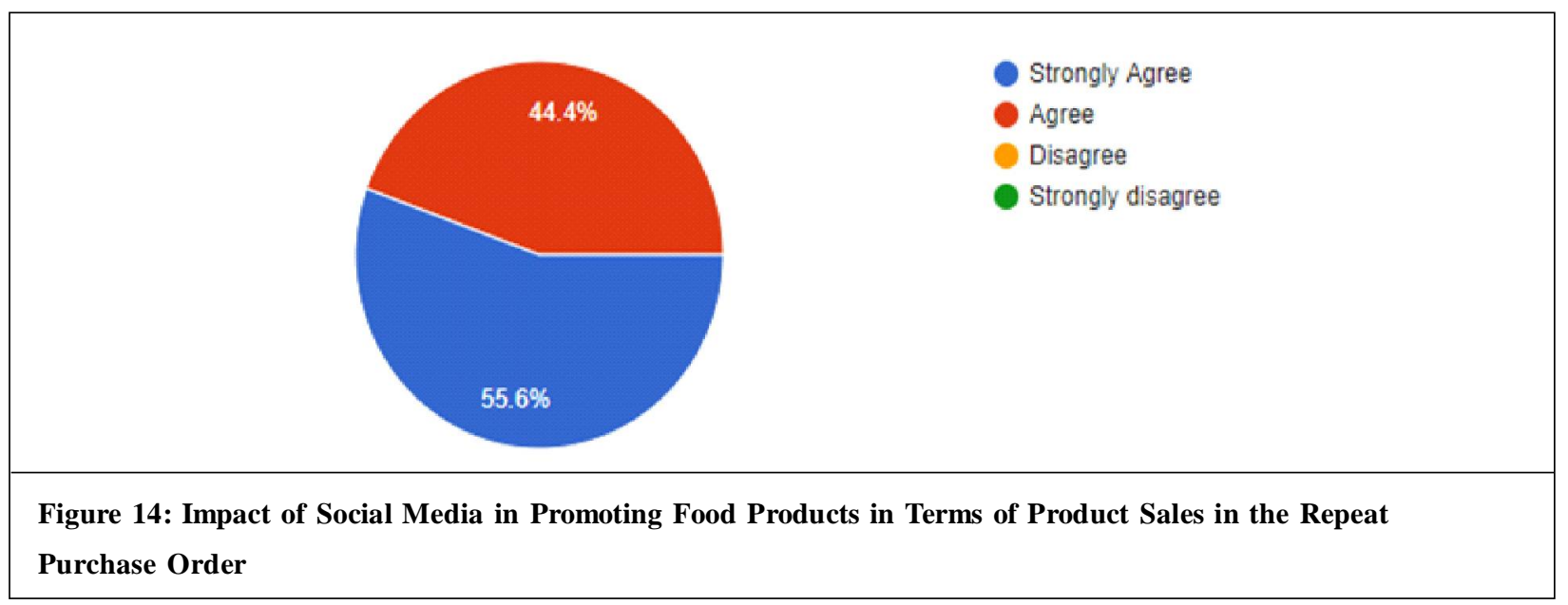

Figure 15 shows that 15 or $57.7 \%$ are strongly agree that social media help improve the product sales in the inventory of stocks, 6 or $23.1 \%$ are agree, 5 or $19.2 \%$ are disagree, and none strongly disagree. Managing inventory of stock online helps improve product sales than the manual inventory system which affects the product sales.

Figure 16 shows that 17 or $63 \%$ are strongly agree that social media is an important communication channel for business for marketing, 10 or $37 \%$ are Agree, and none answered disagree and strongly disagree. This shows that social media is essential in promoting food products.

Figure 17 shows that 17 or $65.4 \%$ strongly agree that social media is an important communication channel for business for promotion, 9 or $34.6 \%$ are agree, and none answered disagree and strongly disagree. The data revealed that 

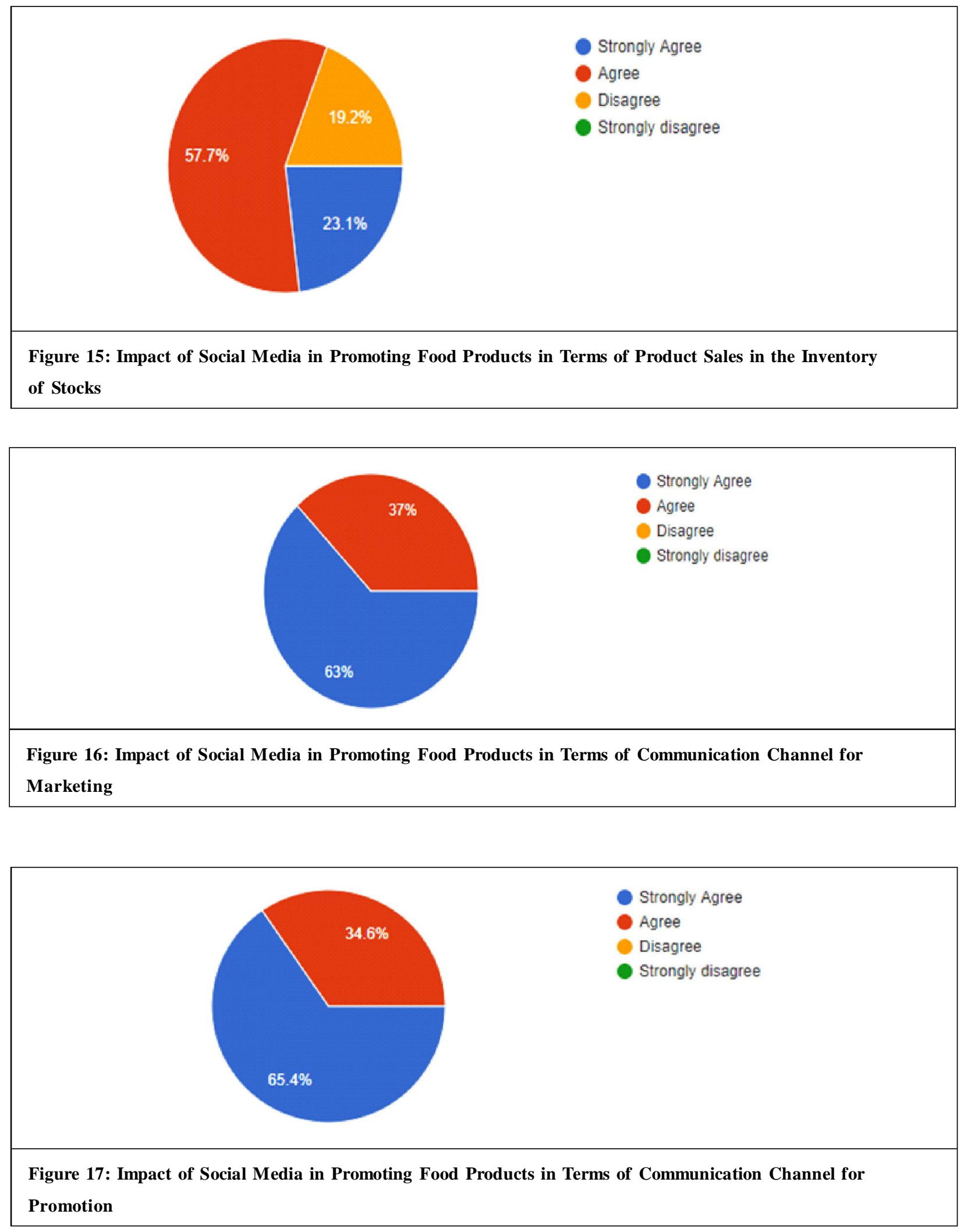

social media platforms, particularly Facebook, help you associate with your customers, improve responsiveness about your products and services, and increase your sales.

Figure 18 shows that 17 or $63 \%$ are strongly agree that social media is an important communication channel for business for sales, 8 or $29.6 \%$ agree, 2 or $7.4 \%$ disagree, and none answered strongly disagree. The data shows that using Facebook in promoting food products boost sales. 


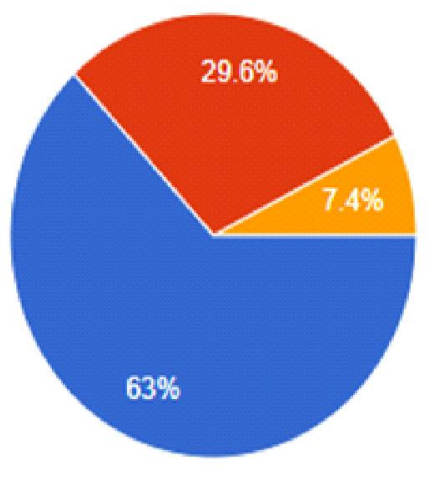

Strongly Agree

Agree

Disagree

Strongly disagree

Figure 18: Impact of Social Media in Promoting Food Products in Terms of Communication Channel for Sales

Table 1: Interview and Transcript

\begin{tabular}{|c|c|}
\hline Online Business (OB) & Answer \\
\hline \multicolumn{2}{|c|}{ Question\#1 Why do you choose that social media in promoting your food products? } \\
\hline OB 1 & This is the center of life \\
\hline OB2 & Used by most people \\
\hline OB3 & It can reach a lot of $\mathrm{FB}$ users \\
\hline OB4 & To engage more potential buyers \\
\hline OB5 & Easy to promote products and easy to ride the trend \\
\hline OB6 & It is cost efficient and time saving \\
\hline OB7 & Has wide range of potential customers \\
\hline OB8 & The most accessible platform for all potential customers \\
\hline OB9 & Social media offers many benefits to business owners \\
\hline OB 10 & It makes it easier to show other people the products \\
\hline OB11 & To reach wider audience \\
\hline OB 12 & Allows us an immediate interaction and engaging with customers \\
\hline OB 13 & It is the best way for me to sell my product \\
\hline OB14 & More customers and chances to endorse your food product \\
\hline OB 15 & It is accessible to everyone \\
\hline OB 16 & On social media many people are seeing our food product \\
\hline OB 17 & I can market my products without me spending money \\
\hline OB 18 & It is much easier to reach to everyone \\
\hline OB19 & Social media is the biggest influence \\
\hline
\end{tabular}




\begin{tabular}{|c|c|}
\hline Online Business (OB) & Answer \\
\hline OB20 & Very accessible, free and convenient \\
\hline OB21 & It's so visible all over the social app \\
\hline OB22 & The most effective way to communicate with your audience \\
\hline OB23 & Business is fire; social media is the fuel \\
\hline OB24 & I truly believe many people can easily see my products \\
\hline OB25 & Big help to make our products more visible \\
\hline OB26 & We earned many loyal customers \\
\hline OB27 & People nowadays they are more focused on social media \\
\hline OB28 & This saves me time and effort which is essential for business \\
\hline OB29 & People no longer go out to buy foods. Because here I get a lot of buyers \\
\hline OB30 & This platform would be more effective \\
\hline \multicolumn{2}{|c|}{ Question\#2 Are you satisfied with the social media you are using? Why? } \\
\hline OB 1 & Yes, I can reach and know different people who are interested in our product \\
\hline OB2 & Yes, I observe that there are people who come to our store from different places to inquire \\
\hline OB3 & Yes, additional sales/deliveries \\
\hline OB4 & Yes, because we get to interact with buys as smoothly as possible \\
\hline OB5 & Yes, because Facebook is one of the crowded place where all people are there and browsing it \\
\hline OB6 & Yes, it provides leads on my target market \\
\hline OB7 & Yes, I am using right now for it helps in promoting our food shop in easier way with less hassle \\
\hline OB8 & Yes, because our sales and orders keep on increasing because of Facebook and Instagram \\
\hline OB9 & I'm using like Facebook page, due to this social networking site allows to have conversations with customers \\
\hline OB 10 & Yes, I am satisfied because it makes it easier and faster to sell the product \\
\hline OB11 & Yes, because of the social media platforms that we've been using we were able to create a brand awareness \\
\hline OB12 & Yes, because it helps us to improve brand loyalty and build stronger customer relationship \\
\hline OB13 & Yes, using social media I can easy make any conversation w/my buyers, friends and family \\
\hline OB14 & Yes, of course because almost $100 \%$ of business man are using social \\
\hline OB 15 & Yes, I am, it really helps my business \\
\hline OB 16 & Yes, I do very satisfy with what social media I've used right now \\
\hline OB 17 & Yes, I'm satisfied because it is effective \\
\hline
\end{tabular}




\begin{tabular}{|c|c|}
\hline Online Business (OB) & Answer \\
\hline OB 18 & Yes. It's better than giving away flyers \\
\hline OB 19 & Yes, because it is convenient and energy saver \\
\hline OB20 & I am satisfied of course; it really helps boosting my sales \\
\hline OB21 & Yes, I am. Social media make the marketing so easy \\
\hline OB22 & Yes, because Facebook which gives us the opportunity to connect with friends and family \\
\hline OB23 & Yes. This generation spends more time in social media \\
\hline OB24 & Yes, I'm satisfied. It helps me to boost my sales \\
\hline OB25 & Yes. Because we are new in this kind of business \\
\hline OB26 & Yes. Because if you post your product more Internet users can see it \\
\hline OB27 & Yes, because this can give us more \\
\hline OB28 & Yes, because Facebook is doing a good job \\
\hline OB29 & Yes, I am satisfied because when I use social media I make money \\
\hline OB30 & I am satisfied, using Facebook is very effective instrument to use in running a business \\
\hline \multicolumn{2}{|c|}{ Question\#3 How often do you update your content in the social media? } \\
\hline OB 1 & Normally once a month or sometimes \\
\hline OB2 & Every time we have changes \\
\hline OB3 & Everyday \\
\hline OB4 & Frequently \\
\hline OB5 & Every time we have new launch products \\
\hline OB6 & I try to update it every day \\
\hline OB7 & We post mostly every day \\
\hline OB8 & We post almost every day \\
\hline OB9 & $2-3$ times only per week \\
\hline OB 10 & More often especially when the internet is fast \\
\hline OB11 & As much as possible every other week \\
\hline OB 12 & We update our social media content every day \\
\hline OB13 & Almost every day \\
\hline OB 14 & If we are having a promos and new flavor with the product \\
\hline OB15 & Once a week \\
\hline
\end{tabular}


Table 1 (Cont.)

\begin{tabular}{|c|c|}
\hline Online Business (OB) & Answer \\
\hline OB 16 & As much as possible every day \\
\hline OB 17 & I'm updating it twice or thrice a week \\
\hline OB 18 & Almost every day \\
\hline OB 19 & Almost every day \\
\hline OB20 & I update my content once a week \\
\hline OB2 1 & Every time the app requires to update \\
\hline OB22 & At least $2-3 \mathrm{x}$ a week \\
\hline OB23 & Once or twice a day \\
\hline OB24 & I update our social media accounts every day \\
\hline OB25 & Every day if I had a chance \\
\hline OB26 & Usually weekly or every other day \\
\hline OB27 & Every day \\
\hline OB28 & At least once day \\
\hline OB29 & 3 to 4 a week \\
\hline OB30 & Every time we had a new product \\
\hline
\end{tabular}

Question\#4 Do you use the feedbacks you got from social media to improve your products and services? How are you implementing those feedbacks?

\begin{tabular}{|l|l|}
\hline OB1 & Yes, because we follow their advice \\
\hline OB2 & Yes, but not all \\
\hline OB3 & Yes, by creating or trying our customer's suggestions to make them pleased \\
\hline OB4 & Yes, by working and executing them as a team \\
\hline OB5 & Feedbacks are the guides of every products and store or company \\
\hline OB6 & Yes, I do. I take them constructively and use them to improve my products \\
\hline OB7 & We improve our customer service and product quality based on feedbacks we're given \\
\hline OB8 & Yes, of course. Good and bad feedbacks are very much appreciated \\
\hline OB9 & Yes, customer feedback is very important. "Feedback is the breakfast of champions \\
\hline OB10 & Yes, I use their good comments to get leads from other people to buy the product \\
\hline OB11 & Yes, we acknowledge and respond so that customers are aware that we're listening to them \\
\hline OB12 & Yes, we use the feedbacks we got from social media to improve our products \\
\hline
\end{tabular}




\begin{tabular}{|c|c|c|}
\hline Online Business (OB) & \multicolumn{2}{|c|}{ Answer } \\
\hline OB 13 & \multicolumn{2}{|c|}{ Yes, it helps to attracts more buyers that is good for my small business } \\
\hline OB 14 & \multicolumn{2}{|c|}{ Yes, the feedback coming from the customer can help us to improve } \\
\hline OB 15 & \multicolumn{2}{|c|}{ Yes, feedbacks are important to me, whether it's bad, because it can help me to get my products better } \\
\hline OB 16 & \multicolumn{2}{|c|}{ Yes, it's a big help for me to used feedback at least we prove the other customer that we can give the satisfaction } \\
\hline OB17 & \multicolumn{2}{|c|}{ Yes, I'm using it. Feedbacks play a big role in any businesses' success so I'm always considering it } \\
\hline OB 18 & \multicolumn{2}{|c|}{ Yes, we used it to improve the quality of our products } \\
\hline OB 19 & \multicolumn{2}{|c|}{ Yes. For us being online seller, feedbacks are the most important thing } \\
\hline OB20 & \multicolumn{2}{|l|}{ Yes, I do. Their feedbacks are important } \\
\hline OB21 & \multicolumn{2}{|c|}{ Yes, customer's feedback is important to make the business to improve } \\
\hline OB22 & \multicolumn{2}{|c|}{ Feedback, comments and suggestion are very much needed to improve your product } \\
\hline OB23 & \multicolumn{2}{|c|}{ Yes, by accepting positive and negative feedbacks and improving the product } \\
\hline OB24 & \multicolumn{2}{|c|}{ Yes, it will be helpful for us if the customers will give suggestions } \\
\hline OB25 & \multicolumn{2}{|c|}{ Yes. Because I still believe that customers are always right } \\
\hline OB26 & \multicolumn{2}{|l|}{ We appreciate our customer's feedback to us } \\
\hline OB27 & \multicolumn{2}{|c|}{ Yes, for us to improve more and exceeds their expectations } \\
\hline OB28 & \multicolumn{2}{|c|}{ It's very much needed to be able to serve the customers better and give them the quality they want } \\
\hline OB29 & \multicolumn{2}{|c|}{ Yes, I use their feedback to find out what my customers want } \\
\hline OB30 & \multicolumn{2}{|c|}{ I believe that the feedbacks from my customers are important } \\
\hline \multicolumn{3}{|c|}{$\begin{array}{l}\text { Question\#5 What do you think are the advantages and disadvantages of promoting your food products in social } \\
\text { media platforms? }\end{array}$} \\
\hline & Advantage & Disadvantage \\
\hline OB 1 & Less cost of promoting products & Sometimes our products or even our own material was imitating \\
\hline OB2 & FB makes possible to know our product & People might pirate our product \\
\hline OB3 & We reach a lot customer for deliveries & Competitors create/make the same products as we serve \\
\hline OB4 & Sales boost and good marketing strategy & $\begin{array}{l}\text { One from the team should devote his/her time to } \\
\text { manage and maintain such platform }\end{array}$ \\
\hline OB5 & Good and easy way to access the products & $\begin{array}{l}\text { Easy to the competitors to copy the post, products, } \\
\text { and strategies of selling }\end{array}$ \\
\hline OB6 & $\begin{array}{l}\text { It is way easier to promote any business } \\
\text { through social media }\end{array}$ & $\begin{array}{l}\text { One negative feedback posted online, even } \\
\text { if untrue, can ruin a business }\end{array}$ \\
\hline
\end{tabular}




\begin{tabular}{|c|c|c|c|}
\hline \multirow[t]{2}{*}{ Online } & \multirow[t]{2}{*}{ Business (OB) } & \multicolumn{2}{|c|}{ Answer } \\
\hline & & Advantage & Disadvantage \\
\hline OB7 & & $\begin{array}{l}\text { Promoting food products in social media } \\
\text { platforms is much easier }\end{array}$ & Customer's negative feedback \\
\hline OB8 & & $\begin{array}{l}\text { We can reach thousands of people by just } \\
\text { simply posting and sharing posts }\end{array}$ & $\begin{array}{l}\text { People keep on asking the actual size of our products } \\
\text { since they can only see it via photos }\end{array}$ \\
\hline OB9 & & $\begin{array}{l}\text { Social media allow you to communicate on } \\
\text { a personal basis with individual customers } \\
\text { and groups }\end{array}$ & Wasted time and money for little or no tangible return \\
\hline OB 10 & & $\begin{array}{l}\text { More people see products and can easily } \\
\text { offer to your other friends }\end{array}$ & $\begin{array}{l}\text { If you do not know how to social media you can be } \\
\text { fooled by people or scammed }\end{array}$ \\
\hline OB 11 & & $\begin{array}{l}\text { It creates brand awareness, brand } \\
\text { reputation, and cost-effective. }\end{array}$ & Exposure to negative reviews and time consumptive \\
\hline OB 12 & & $\begin{array}{l}\text { This can set us apart from our } \\
\text { competition }\end{array}$ & $\begin{array}{l}\text { There are people who always aim to damage one's } \\
\text { reputation }\end{array}$ \\
\hline OB 13 & & $\begin{array}{l}\text { Social media is more people and } \\
\text { more interested buyers will approach }\end{array}$ & Sometimes buyer's expectation didn't met \\
\hline OB 14 & & $\begin{array}{l}\text { Having lot of people whom can reach } \\
\text { your business or product }\end{array}$ & $\begin{array}{l}\text { We're having a scam customer or having a competitor } \\
\text { and same business }\end{array}$ \\
\hline OB 15 & & $\begin{array}{l}\text { It is totally free, you just need to post } \\
\text { it and share it to your friends }\end{array}$ & $\begin{array}{l}\text { Some people may copy your product when they see } \\
\text { that it's successful }\end{array}$ \\
\hline OB 16 & & $\begin{array}{l}\text { It's a free promotion and many people } \\
\text { will see it }\end{array}$ & I don't know if its scam or not \\
\hline OB 17 & & $\begin{array}{l}\text { It's free, very accessible, and you can } \\
\text { reach many people }\end{array}$ & $\begin{array}{l}\text { Anybody can put negative reviews on it which will } \\
\text { greatly affect your business }\end{array}$ \\
\hline OB 18 & & Everyone is on social media every day & $\begin{array}{l}\text { When the customer doesn't have internet connection } \\
\text { or don't use data }\end{array}$ \\
\hline OB 19 & & Most of the people are using social media & $\begin{array}{l}\text { False/fake news advertisement; scammers are still } \\
\text { everywhere }\end{array}$ \\
\hline OB20 & & Social media is accessibility & $\begin{array}{l}\text { I have to answer all the comments and messages } \\
\text { I receive and it consumes a lot of time }\end{array}$ \\
\hline OB21 & & $\begin{array}{l}\text { More people can see and might get } \\
\text { interested in your food products }\end{array}$ & $\begin{array}{l}\text { It may take time for your business to kick in the } \\
\text { market }\end{array}$ \\
\hline OB22 & & Positive feedback & Negative feedback \\
\hline OB23 & & $\begin{array}{l}\text { Accessibility, engagement, promotion, } \\
\text { marketing }\end{array}$ & Plagiarism \\
\hline
\end{tabular}




\begin{tabular}{|c|c|c|}
\hline Online Business (OB) & \multicolumn{2}{|c|}{ Answer } \\
\hline & Advantage & Disadvantage \\
\hline OB24 & $\begin{array}{l}\text { My product will be known easily by } \\
\text { many people }\end{array}$ & $\begin{array}{l}\text { Not all people who see my post or content is nearby } \\
\text { to my store }\end{array}$ \\
\hline OB25 & $\begin{array}{l}\text { More ways to visit FB page if you want to } \\
\text { know what's in the menu }\end{array}$ & $\begin{array}{l}\text { Can sabotage us just only by commenting negative } \\
\text { feedback }\end{array}$ \\
\hline OB26 & $\begin{array}{l}\text { Social media have wide scope. Social } \\
\text { media are really easy to use }\end{array}$ & $\begin{array}{l}\text { Some of our customers doubt our products to be } \\
\text { freshly good }\end{array}$ \\
\hline OB27 & It is for our guests to be notified easily & It is the contents and the competitors \\
\hline OB28 & $\begin{array}{l}\text { Being able to be known by many people } \\
\text { just by posting }\end{array}$ & $\begin{array}{l}\text { Competitors can easily get idea on how to make } \\
\text { advertisements like yours }\end{array}$ \\
\hline OB29 & $\begin{array}{l}\text { Many clients, easy way for people to get } \\
\text { to know you }\end{array}$ & When a customer posts negative feedback \\
\hline OB30 & $\begin{array}{l}\text { You can reach and stay connected to } \\
\text { your target audience anytime }\end{array}$ & $\begin{array}{l}\text { Negative review becomes visible to all your followers, } \\
\text { including your current and potential customers }\end{array}$ \\
\hline
\end{tabular}

\section{Discussion}

Findings from this research indicate that the majority of internet food product businesses were less than a year old because those were the times when employment were lost owing to the pandemic's lockdown. People were confined at home, thus there was a high demand for food delivery. Various food items had become marketable. During the lockdown, the only thing to do is eat because it is what most Filipinos like. Social media has been shown to be superior to traditional marketing because it can reduce marketing and promotion expenditures while also providing a competitive advantage in labor costs. Because practically everyone prefers to learn about new products through digital means, social media marketing has gained some traction in business. Because of its large reach and public availability, social media promotes consumer satisfaction and product recommendations. Customers are pleased with the food product's ease of access and the quick transaction. Product recommendations are quickly available online for online food product businesses. Fifteen respondents, or $55.6 \%$, strongly agree that social media helps improve product sales in terms of amount purchased, repeat buy orders, and stock inventories. Out of 26 respondents, 17 (or 63\%) strongly agreed that social media is a vital communication tool for businesses for marketing and sales. While 17 (or 63\%) of the 27 respondents strongly agreed that social media is a significant communication medium for business marketing. Because Facebook is the most popular social media network, internet retailers and food businesses use it. It is the fastest means to get in touch with current and potential consumers. Most online food businesses that often update their webpage seek to be more engaging and create strong client relationships. Almost all online food businesses utilize positive comments as part of their promotional strategy. At the same time, they all appear to be experimenting with the clients' recommendations. The benefits of social media in promoting food goods that were highlighted in the research are all genuine. To set up a business platform, all you need is a computer, a Facebook account, and an internet connection. There are no structures to construct, no permissions to obtain, and the fact that it is open to the public makes it simpler to attract potential clients. It is inevitable that you will receive bad feedback on your foodstuff products, no matter how fantastic they are. Facebook Marketplace was designed to be a community-focused tool that brought people together to purchase and sell items. It has no additional payment mechanism; all you need to access the service is a profile. Uploading a photo, deciding on a pricing, uploading, and marketing are all basic processes. The disadvantage is that it is a haven for fraudsters. 


\section{Conclusion}

Food products have always been sellable; however, it is advised to follow the trend. In order to reach a larger market, it is also preferable to use other social media sites such as Twitter, Instagram, YouTube, and others rather than focusing just on Facebook. Social networking is quite popular with both products and viewers. If your items are not available on any social media site, you are missing out on the opportunity to run a profitable business. The same is true if you are on social media but are not interacting or connecting with your target market and are having problems successfully sustaining your social approach. It is therefore suggested that online businesses that want to stay ahead of the competition use social media marketing services such as social media strategy development, social page optimization, social media campaign development and management, paid social ads setup and management, community building and management, and multimedia content creation and publication. You may anticipate a greater reach, valuable exposure, better visibility, more followers, higher engagement, higher conversion rates, enhanced brand trust, more leads, and higher sales at the absolute least. As a food product, your material must be visually appealing. You must have images or visuals that your viewers can relate to, so make the most of your photographs. The importance of visual marketing strategy in product recognition cannot be overstated. It is also advised that you present your product story with appropriate and consistent images in order to have a more dominating and long-term influence. To do so, create a content calendar with graphics and sketch out the subject for each day of the week, ideally many weeks in advance. Make sure to include all of the necessary hashtags in this social calendar. In addition, seek for potential influencers and collaborate with them to increase your food product advertising. Viewers see a prominent influencer sharing a product on social media as more genuine than any premium marketing. However, be cautious of who you partner with, choose the right collection of influencers, and be really excited about food and an expert in this field. The benefits of using social media to promote food goods are numerous. However, drawbacks such as unfavorable remarks and fake purchasers will undoubtedly make life difficult for you. Negative feedback should not be ignored. It will give an irritated client another causes to reject your food offerings. You must respond with every word, whether favorable, negative, or neutral. Maintaining public relations is essential for product development. When dealing with negative remarks about your food products, make sure not to replace them or refund the money simply because your customers are unhappy. Examine the problem first, then explain how you plan to solve it. It is difficult to remain calm, but in order to save your company, you must always be courteous. To resolve a disagreement, request that the consumer message you directly, phone you, or send you an email. Consider negative comments as sources of information from which you may discover what your clients dislike about your items. Another downside of advertising things on social media is the presence of bogus buyers. It is advised that internet sellers be technologically knowledgeable in order to avoid online frauds. Keep up to date on the newest advances in security and privacy. Be wary of anyone you trade with online, and use extreme caution.

\section{References}

Alzyoud, M.F. (2018). Social Media Marketing, Functional Branding Strategy and Intentional Branding. Problems and Perspective in Management Journal, 16(3), 102-116.

Bayer, J. and Servan-Schreiber, E. (2011). Gaining Competitive Advantage Through the Analysis of Customers' Social Networks. Journal of Direct, Data and Digital Marketing Practice, 13 (2).

Cetiña, I., Mircea, F., Stoicescu, C., Dumitrescu, L. and Orzan, G. (2018). Modelling the Influences of Online Social Networks on Consumer's Buying Behaviour. Economic Computatio and Economic Cybernetics Studies and Research, 52(2), 5-20.

Fajar, A. and Endi, S. (2020). How Social Media Marketing Influences Consumers Purchase Decision? A Mediation Analysis Of Brand Awareness. JEMA Jurnal Ilmiah Bidang Akuntansi dan Manajemen, 17(2), 156.

Fitz Gerald, R. (2019). The Impact of Social Media to Consumer Buying Behavior. https://connextdigital.com/how-socialmedia-impact-consumer-buying-behavior/

Hennig-Thurau, T., Gwinner, K., Walsh, G. and Gremler, D. (2004). Electronic Word of Mouth Via Consumer Opinion Platrforms: What Motivates Consumers to Articulate Themselves on the Internet. Jounal of Interactive Marketing, 18(1), 38-52. https://doi.org/10.1002/dir.10073

Jones, N., Borgman, R. and Ulusoy, E. (2015). Impacts of Social Media on Small Businesses. Journal of Small Business and Enterprise Development, 22(4), 611-632. https://doi.org/10.1108/JSBED-09-2013-0133

Pilař, L., Kvasnièková Stanislavská, L., Kvasnièka, R., Bouda, P. and Pitrová, J. (2021). Framework for Social Media Analysis Based on Hashtag Research. Applied Sciences, 11(8):3697. https://doi.org/10.3390/app11083697 
Pietro, L. and Pantano, E. (2012). An empirical investigation of social network influence on consumer purchasing decision: The case of Facebook. Journal of Direct, Data and Digital Marketing Practice, 14(1).

Research Market. (2020). Demand for Food Delivery Explodes During the COVID-19 Pandemic as Consumers SelfIsolate and Restaurants Close Down. https:/www.prnewswire.com/news-releases/demand-for-food-deliveryexplodes-during-the-covid-19-pandemic-as-consumers-self-isolate-and-restaurants-close-down-301049240.html.

Shankar, V., Inman, J., Mantrala, M., Kelley, E. and Rizley, R. (2011). Innovations in Shopper Marketing: Current Insights and Future Research Issues. Journal of Retailing, 87.DOI: 10.1016/j.jretai.2011.04.007.

Whitler, K. (2014). Why Word of Mouth Marketing Is the Most Important Social Media. https://www.forbes.com/sites/ kimberlywhitler/2014/07/17/why-word-of-mouth-marketing-is-the-most-important-social-media/?sh=947a93e54a8c .

Cite this article as: Canet, Lena N., De Luna, Ma. Cecilia E. and Eleogo, Felicidad A. (2021). Impacts of Social Media in Promoting Food Products. International Journal of Tourism and Hospitality. 1(S), S27-S43. https://doi.org/ 10.51483/IJTH.1.S1.2021.S27-S43. 